\title{
Application and Development of an Environmentally Friendly Blast Hole Plug for Underground Coal Mines
}

\author{
Donghui Yang $\mathbb{D}^{1,2,3}$ Yixin Zhao $\mathbb{D}^{1,3}{ }^{1,3}$ Zhangxuan Ning, ${ }^{2}$ Zhaoheng Lv, ${ }^{2}$ and Huafeng Luo ${ }^{2}$ \\ ${ }^{1}$ School of Resource and Safety Engineering, China University of Mining and Technology (Beijing), Beijing 100083, China \\ ${ }^{2}$ School of Coal Engineering, Shanxi Datong University, Datong 037003, China \\ ${ }^{3}$ Beijing Key Laboratory for Precise Mining of Intergrown Energy and Resources, China University of Mining and Technology (Beijing), \\ Beijing 100083, China
}

Correspondence should be addressed to Donghui Yang; ydhname@163.com

Received 23 June 2017; Accepted 28 December 2017; Published 24 January 2018

Academic Editor: Longjun Dong

Copyright (c) 2018 Donghui Yang et al. This is an open access article distributed under the Creative Commons Attribution License, which permits unrestricted use, distribution, and reproduction in any medium, provided the original work is properly cited.

Drilling and blasting technology is one of the main methods for pressure relief in deep mining. The traditional method for blasting hole blockage with clay stemming has many problems, which include a large volume of transportation, excess loading time, and high labor intensity. An environmentally friendly blast hole plug was designed and developed. This method is cheap, closely blocks the hole, is quickly loaded, and is convenient for transportation. The impact test on the plug was carried out using an improved split Hopkinson pressure bar test system, and the industrial test was carried out in underground tunnel of coal mine. The tests results showed that, compared with clay stemming, the new method proposed in this paper could prolong the action time of the detonation gas, prevent premature detonation gas emissions, reduce the unit consumption of explosives, improve the utilization ratio, reduce the labor intensity of workers, and improve the effect of rock blasting with low cost of rock breaking.

\section{Introduction}

With the increase of coal mining depth, a large number of coal mines have entered deep mining in China $[1,2]$. Deep mining faces the problem of high in situ stress, in order to maintain the stability of surrounding rock of roadway and working face, drilling and blasting technology is needed for pressure relief $[3,4]$. Blasting will lead to the occurrence of large microseismic events, so the energy accumulated in the rock mass can be released [5-7].

Drilling and blasting technology is one of the main methods for breaking mining rocks for a long time. In order to improve the blasting effect, blasting hole blockage is often needed. Blasting hole blockage is an important part of blasting construction and also one of the important factors affecting the blasting effect [8]. Many theories and practices [9] prove that, compared with nonblocking, good hole blockage could limit the early emissions of detonation gas from the stemming region, prolong the action time of the detonation gas, promote sufficient explosive reaction, improve the utilization ratio of explosive blasting, increase the blasting range of fractured rock mass, improve the blasting effect, reduce the generation of dust and harmful gases, prevent the spray of hot solid particles and the explosion flame, and effectively prevent gas explosion and coal dust explosion.

The movement of hole stemming in the hole is the result of the joint action of many factors, including explosive shock wave, detonation gas generator, hole wall friction resistance, and its own inertial resistance [10]. The plugging effect mainly depends on the plugging material and block length. Various types of blast hole blockages are summarized, and the advantages and disadvantages of different kinds of stemming and their application ranges are analyzed in Table 1. According to the properties of the materials, blast hole blockage can be divided into four categories: loose solid, compressive fluid, expansion colloid, and mechanical structure.

Many scholars [11-16] have studied loose solid blocking materials such as sand, debris, and clay. The results show that granular materials with multiple edges could achieve good blockage effect, and reasonable stemming material type and particle size could increase the stemming volume by 
TABLE 1: Classification of hole stemming.

\begin{tabular}{|c|c|c|c|c|c|c|}
\hline Class & Material & Name & Advantages & Disadvantages & Use & References \\
\hline \multirow{4}{*}{ (a) } & \multirow{4}{*}{$\begin{array}{l}\text { Rock powder, sand, clay, } \\
\text { water and their } \\
\text { mixtures, and so on }\end{array}$} & Clay & $\begin{array}{l}\text { Strong plasticity, good } \\
\text { blockage effect, low cost }\end{array}$ & $\begin{array}{l}\text { Large volume of } \\
\text { transportation, long } \\
\text { loading time }\end{array}$ & \multirow{4}{*}{ (i) } & $\begin{array}{l}\text { Cummins and } \\
\text { Given, } 1973\end{array}$ \\
\hline & & Sand & $\begin{array}{l}\text { General blockage effect, } \\
\text { high density }\end{array}$ & $\begin{array}{l}\text { Large volume of } \\
\text { transportation, long } \\
\text { loading time, used with } \\
\text { clay }\end{array}$ & & Konya, 1996 \\
\hline & & Rock powder & $\begin{array}{l}\text { General blockage effect, } \\
\text { low cost }\end{array}$ & $\begin{array}{l}\text { Large volume of } \\
\text { transportation, long } \\
\text { loading time }\end{array}$ & & $\begin{array}{l}\text { Sharma and Rai, } \\
2015\end{array}$ \\
\hline & & $\begin{array}{l}\text { A mixture of } \\
\text { clay, sand, } \\
\text { and water }\end{array}$ & $\begin{array}{l}\text { Composite blockage, } \\
\text { good blockage effect }\end{array}$ & $\begin{array}{l}\text { High operating } \\
\text { requirements, large } \\
\text { volume of } \\
\text { transportation, long } \\
\text { loading time }\end{array}$ & & $\begin{array}{c}\text { Choudhary and } \\
\text { Rai, } 2013\end{array}$ \\
\hline \multirow{4}{*}{ (b) } & \multirow{4}{*}{$\begin{array}{l}\text { Water, air, aqueous } \\
\text { solution, gel material, } \\
\text { and so on }\end{array}$} & $\begin{array}{l}\text { Water } \\
\text { injection }\end{array}$ & $\begin{array}{l}\text { Reduces dust and } \\
\text { harmful gas }\end{array}$ & $\begin{array}{l}\text { Small friction, cannot be } \\
\text { used alone }\end{array}$ & (i) & $\begin{array}{c}\text { Unver and } \\
\text { Ozozen, } 1998\end{array}$ \\
\hline & & Gas injection & $\begin{array}{l}\text { Reduces dust and } \\
\text { harmful gas }\end{array}$ & $\begin{array}{l}\text { Small friction, cannot be } \\
\text { used alone }\end{array}$ & (ii) & Kang, 2006 \\
\hline & & Gel & $\begin{array}{l}\text { Reduces dust and } \\
\text { harmful gas, good } \\
\text { blockage effect }\end{array}$ & $\begin{array}{l}\text { Slow setting and } \\
\text { hardening, complex } \\
\text { process }\end{array}$ & (i) & Wang, 2007 \\
\hline & & Surfactant & $\begin{array}{l}\text { Reduces dust and } \\
\text { harmful gas, good } \\
\text { blockage effect }\end{array}$ & Polluted air, high cost & (i) & Jin et al., 2007 \\
\hline \multirow{3}{*}{ (c) } & \multirow{3}{*}{$\begin{array}{l}\text { Expansion agent, } \\
\text { accelerator, } \\
\text { early strength agent, } \\
\text { water glass, cement, } \\
\text { gypsum, and so on }\end{array}$} & $\begin{array}{l}\text { Water- } \\
\text { absorbent } \\
\text { rubber }\end{array}$ & $\begin{array}{l}\text { General blockage effect, } \\
\text { low cost }\end{array}$ & $\begin{array}{l}\text { Poor blockage effect, } \\
\text { used with water } \\
\text { stemming }\end{array}$ & (i) & Wang et al., 2015 \\
\hline & & $\begin{array}{l}\text { Organic } \\
\text { quick-setting }\end{array}$ & $\begin{array}{l}\text { General blockage effect, } \\
\text { low cost }\end{array}$ & $\begin{array}{l}\text { Used with pressure and } \\
\text { water stemming }\end{array}$ & (iii) & $\begin{array}{l}\text { Marinho et al., } \\
2017\end{array}$ \\
\hline & & $\begin{array}{l}\text { Inorganic } \\
\text { quick-setting }\end{array}$ & $\begin{array}{l}\text { General blockage effect, } \\
\text { low cost }\end{array}$ & $\begin{array}{l}\text { Used with pressure and } \\
\text { water stemming }\end{array}$ & (iii) & $\begin{array}{l}\text { Cevizci and } \\
\text { Özkahraman, } \\
2011 \\
\end{array}$ \\
\hline \multirow{5}{*}{ (d) } & \multirow{5}{*}{$\begin{array}{l}\text { Plastic, rubber, wood, } \\
\text { ceramic, and so on }\end{array}$} & $\begin{array}{l}\text { Bottom cone } \\
\text { plug }\end{array}$ & $\begin{array}{l}\text { General blockage effect, } \\
\text { easy to use }\end{array}$ & Cannot be used alone & \multirow{5}{*}{ (iv) } & Skaggs, 1998 \\
\hline & & Wedge plug & $\begin{array}{l}\text { General blockage effect, } \\
\text { easy to use }\end{array}$ & $\begin{array}{l}\text { Preloading, stemming } \\
\text { sealing again }\end{array}$ & & Worsey, 1993 \\
\hline & & $\begin{array}{l}\text { Spherical } \\
\text { plug }\end{array}$ & $\begin{array}{l}\text { General blockage effect, } \\
\text { easy to use }\end{array}$ & $\begin{array}{l}\text { Preloading, stemming } \\
\text { sealing again }\end{array}$ & & $\begin{array}{l}\text { S. Jenkins and T. } \\
\text { S. Jenkins, } 2001\end{array}$ \\
\hline & & $\begin{array}{l}\text { Spiral burst } \\
\text { plug }\end{array}$ & $\begin{array}{l}\text { Good blockage effect, } \\
\text { easy to use }\end{array}$ & Complex structure & & Shann, 2002 \\
\hline & & $\begin{array}{l}\text { Combination } \\
\text { plug }\end{array}$ & $\begin{array}{l}\text { Good blockage effect, } \\
\text { easy to use }\end{array}$ & Complex structure & & $\begin{array}{l}\text { Sazid et al., } \\
\quad 2011\end{array}$ \\
\hline
\end{tabular}

(a) Loose solid; (b) compressive fluid; (c) expansion colloid; (d) mechanical structure; (i) widely used; (ii) air interval blasting; (iii) large diameter pole; and (iv) special diameter pole.

$41 \%$. When the average particle size of stemming is $1 / 25$ of the blast hole diameter, the blockage length is the shortest, and the blockage effect is the best. Water stemming and air stemming have a small hole wall friction resistance and cannot be used alone. When they are used, the blast hole orifice should also be filled with a certain length of loose solid materials. Plaster stemming [17], non-Newtonian fluid mixture [18], gel stemming [19], and so on have sufficient strength, but the hardening speed is slow and the cost is high.
Accordingly, various types of novel blast hole plugs of the mechanical structure have been developed [20-26]. They are made of plastic, wood, rubber, ceramics, and other raw materials, with structures such as bottom cone, wedge, spherical, spiral bursting, and combination. The blockage effects are uneven. The length and diameter of the plug should be designed according to the specific blast conditions. When a blast hole plug is used, a certain amount of pressure is often required in advance, or clay, sand, and other loose materials should be used to block the blast hole orifice again; otherwise, 
the blockage effect is unsatisfactory. At present, there are few studies on the mechanical structure plug, which can be used alone and whose blockage effect is good, let alone the formation of serialized products.

At present, a large amount of clay and its mixtures are being used to produce the stemming in coal mines in China. Since problems such as a large volume of transportation and long loading time have existed in blast pole stemming, the workers would often adopt reverse charge with nonblocking, or they would simply increase the explosive charge in order to save working hours and reduce the labor intensity. Therefore, many problems have occurred, such as reduction of the utilization ratio of explosive energy, serious overexcavation and underexcavation of the surrounding rock, and the poor formation of the section [27-32].

According to the aforementioned problems, in order to enhance the blockage efficiency and blockage effect, improve the blasting effect, and reduce the labor intensity of workers, an environmentally friendly blast hole plug that is cheap, closely blocks the hole, is quickly loaded, and is convenient for transportation was designed and developed, which combines the advantages and disadvantages of the domestic and foreign mechanical structure plugs. The improved split Hopkinson pressure bar (SHPB) test system was carried out for the blocking impact test of the plug. The industrial test was carried out in 2415 roadway, 404 area, $8^{\#}$ layer of the Yungang Coal Mine of the Datong Coal Mine Group and the return entry of Wuyang Coal Mine in Lu'an Group. The blockage effect of the plug is good, which can offer reference for the development of similar plug products.

\section{Environmentally Friendly Blast Hole Plug Design}

Based on the above analysis of blast hole stemming mechanism, stemming length, and stemming material, in order to obtain better blockage effect, the design of blockage should possess the following properties: it has a certain length; it has a certain density; it has large hole wall friction resistance; it has dispersion and a buffer, and the friction resistance gradually increases with buffer and burst; it has compression function, which could increase the effective cavity and buffer blasting pressure during the movement; it can realize selflocking using an explosive shock wave; it has a certain initial blockage force; it is convenient and cheap.

According to the aforementioned design idea, a new type of environmentally friendly blast hole plug was designed and developed. In contrast to other plugs, the blast hole plug was designed with a composite structure system, including impact plug, multistage bursting cylinder with compressible burst, water stemming inner core with high-efficiency dust reduction and environmental protection, and wedge plug. The blast hole plug is cheap, closely blocks the hole, is quickly loaded, and is convenient for transportation. It exhibits good rock breaking effect and reduces the labor intensity. The plug has the advantages of being flame retardant, antistatic, waterproof, and water-resistant, which could be used for drilling holes with different angles and interval blasting.

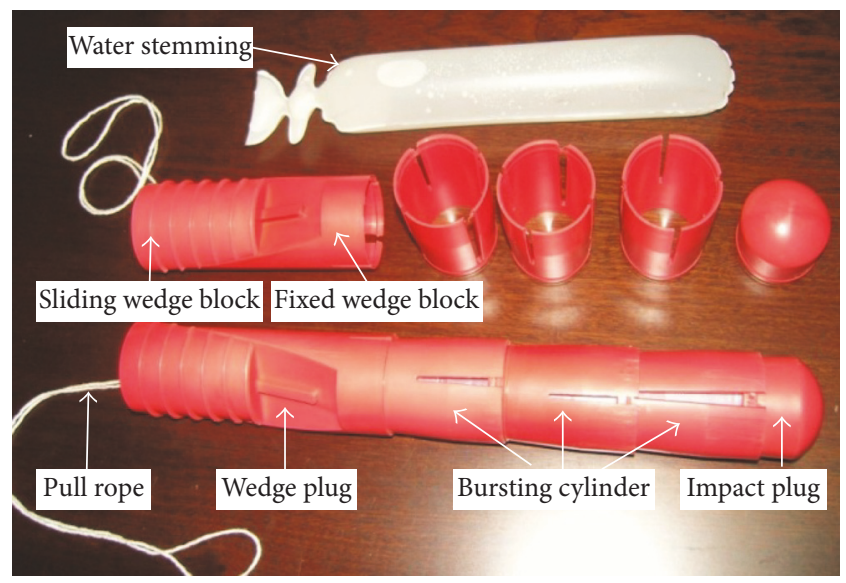

FIgURE 1: The blast hole plug and its components.

The image of the blast hole plug is shown in Figure 1. The plug is made of polyethylene (LDPE) as raw material. Its structure is composed of an impact plug, three bursting cylinders, a wedge plug, environmentally friendly water stemming, and a pull rope. The impact plug is a hollow plug, half of which is a hemisphere and the other half is a cone. The hemispherical structure can fully utilize the reflection principle of explosive shock wave propagation in different media, which can reduce a part of the shock wave. One end of the cone is socketed with a bursting cylinder. The bursting cylinder is a hollow cylinder with certain inner and outer cone angles and four openings that are designed for the rapid expansion of the bursting cylinder. The length of the three openings is half of the cylinder length, and the other opening is as long as the cylinder. The bursting cylinders can be socketed with each other. The socket number depends on the length of the plug. The wedge plug is composed of a fixed wedge block (large) and a sliding wedge block. The water stemming is composed of a polyethylene bag and mixed aqueous solution. The polyethylene bag is obtained via a high-frequency, high-pressure, and high-temperature forming process. The aqueous solution is a mixed liquid with polyethylene glycol, sodium chloride, and ferrous sulfate in a certain proportion. For convenience of application, the plug combination is closely wrapped in a layer of plastic package.

The key to the design of the plug is the diameter and length of the bursting cylinder. The cylinder diameter should be neither too big nor too small. If it is too big, it would be difficult to be loaded. If it is too small, it cannot be closely contacted with the hole wall after complete burst. The bursting cylinder length is closely related to the cone angle. The cone angle is designed to be $4-8^{\circ}$ for full burst after the compression of the bursting cylinder. The borehole diameter of the heading face in a coal mine is usually $42 \mathrm{~mm}$ in China. Therefore, the outer diameter of the bursting cylinder is designed to be $40 \mathrm{~mm}$. The specific parameters of the plug are listed in Table 2. The plug is designed with a total length of $280 \mathrm{~mm}$, weight of $140 \mathrm{~g}$, and cost of 1.1 RMB. It is mainly used in blasting engineering in coal mine underground roadway and chambers and can also be used in the subway, tunnel, 
TABLE 2: Parameters of the blast hole plug.

\begin{tabular}{|c|c|c|c|c|c|c|}
\hline Structure name & $\mathrm{OD}(\mathrm{mm})$ & $L(\mathrm{~mm})$ & deg. $\left({ }^{\circ}\right)$ & $T(\mathrm{~mm})$ & $\rho\left(\mathrm{kg} / \mathrm{m}^{3}\right)$ & $Q(\mathrm{~g})$ \\
\hline Impact plug & 36 & 38 & 6 & 4.0 & 918 & 30 \\
\hline Bursting cylinder & 40 & 57 & 6 & $1-3.5$ & 918 & $10 \times 3$ \\
\hline Wedge plug & 40 & 100 & 14 & $1-3.0$ & 918 & 40 \\
\hline Water stemming & 22 & 200 & - & 0.5 & 1128 & 40 \\
\hline Plug & 40 & 280 & $6 / 14$ & $1-4.0$ & 918 & 140 \\
\hline
\end{tabular}

OD, outside diameter; deg., inner cone angle; $T$, thickness.

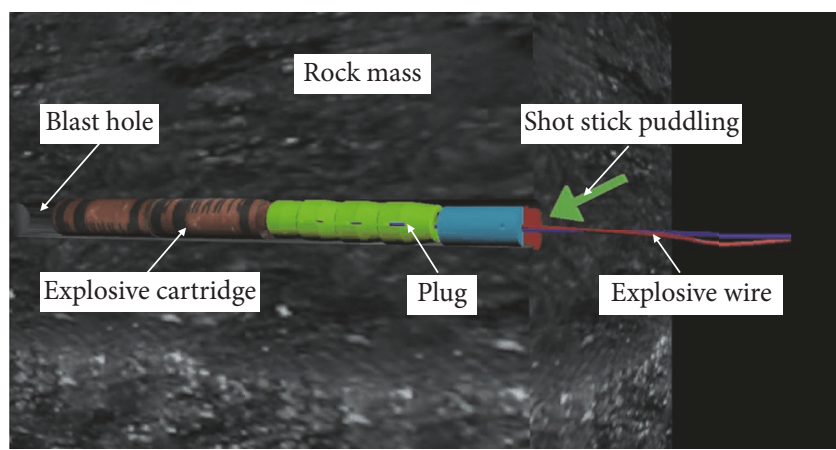

FIGURE 2: Schematic diagram of the blast hole plug and its location in rock mass.

and noncoal mines. With the large-scale application of the products, the cost will be gradually reduced. At present, other series of products (such as those with the diameter of $60 \mathrm{~mm}$, $75 \mathrm{~mm}, 90 \mathrm{~mm}$, and $120 \mathrm{~mm}$ ) are being tested.

When the plug is used, the entire product is manually fed into the orifice. A worker pulls the pull rope fixed on the wedge block and strikes the sliding wedge block using a shot stick as shown in Figure 2, which can provide the initial friction resistance for the movement of the plug and enable the impact plug and bursting cylinder to produce quick multistage horizontal expansion under the action of a detonation gas generator. This type of plug is designed with a composite structure system, which can use an explosive shock wave as a source power of self-bursting, extend the action time of the explosion gas, and improve the utilization ratio of explosive energy. It can also be effectively combined and reasonably configured according to the hole depth and stemming length. The water stemming filled inside the bursting cylinder can achieve flexible compression expansion, increase the friction resistance, and improve the plug strength. The water mist formed after the blasting can result in dust reduction, cooling, flame reduction, and absorption of harmful gases, which could improve the working environment. Therefore, the product is named as hydraulic pressure resistant and environmentally friendly blast hole plug with impact selflocking and increased resistance with water pressure.

\section{Impact Load Test}

3.1. Test Equipment. In order to study the blockage effect of the environmentally friendly blast hole plug, the improved SHPB test system was carried out for the blocking impact test of the plug. The theoretical basis of the SHPB test is based on propagation of a stress wave in elastic rod with uniform stress assumption [33-38]. The test system, as shown in Figure 3, adopts the loading mode of a half sine wave. During the test, a high-pressure gas was injected from the gas gun into the pressure cylinder. The striker in the pressure cylinder was pulled out by the high-pressure gas and impact incident bar. The incident stress wave excited by the impact was transmitted to the simulated blast hole along the incident bar. The strain gauge signal output posted on the incident bar was in the form of a voltage time curve. The typical waveform curves of the sample are shown in Figure 4. The incident stress can be calculated from the measured voltage value of the strain gauge. Based on the law of conservation of energy, the incident energy can be obtained as follows:

$$
E_{I}=\frac{A_{e}}{\rho_{e} C_{e}} \int_{0}^{t} \sigma_{I}^{2}(t) d t
$$

where $E_{I}$ represents the incident energy, $A_{e}$ represents the compression bar sectional area, $\rho_{e}$ represents the compression bar density, $C_{e}$ represents the velocity of stress pulse in the incident bar, and $\sigma_{I}(t)$ represents the incident wave stress of $t$ at a certain time.

In order to obtain test results closer to the actual underground results in a coal mine, the sample loading device of the lower left corner of Figure 3 was used. The device was composed of a steel pipe used for simulating the blast hole and a cylinder steel bar. The inner and outer diameters of the pipe were, respectively, $46 \mathrm{~mm}$ and $60 \mathrm{~mm}$, and the length was $420 \mathrm{~mm}$. The bar diameter was $40 \mathrm{~mm}$, and the length was $500 \mathrm{~mm}$. In order to facilitate observation and record, two grooves were cut on the side of the steel pipe, and a highspeed camera was used to record the dynamic movement of the plug in the blast hole.

3.2. Test Sample. The contrast tests were carried out by using the clay stemming and the plug. Twelve plugs were used as the samples of group A, and their material density was $918 \mathrm{~kg} / \mathrm{m}^{3}$. The bag filled with loess was used as the clay stemming. It was made of yellow paper and cut into a cylinder and was subsequently bound using glue. Its diameter was $40 \mathrm{~mm}$, and length was $300 \mathrm{~mm}$. The loess was from a hill near the Datong Yungang Coal Mine, and its density was $1808-1983 \mathrm{~kg} / \mathrm{m}^{3}$. Eight bags of loess were used as the samples of group B. The test samples are shown in Figure 5.

When the sample was loaded, the clay stemming was puddled by the shot stick to provide the initial friction resistance, and the plug was locked by the wedge plug. The 


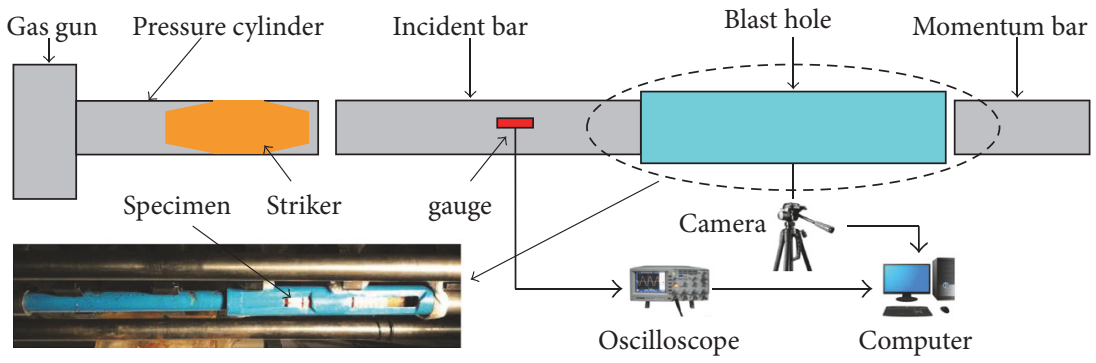

FIGURE 3: Schematic diagram of Hopkinson bar structure improvement in the blocking impact test.

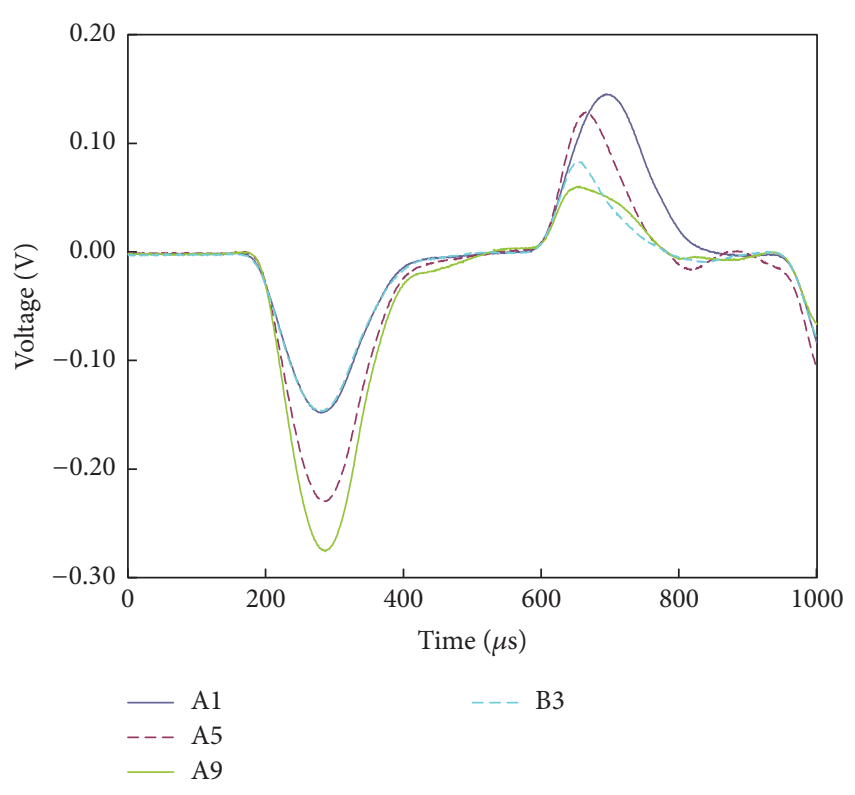

FIGURE 4: Typical waveform of the blocking impact test.

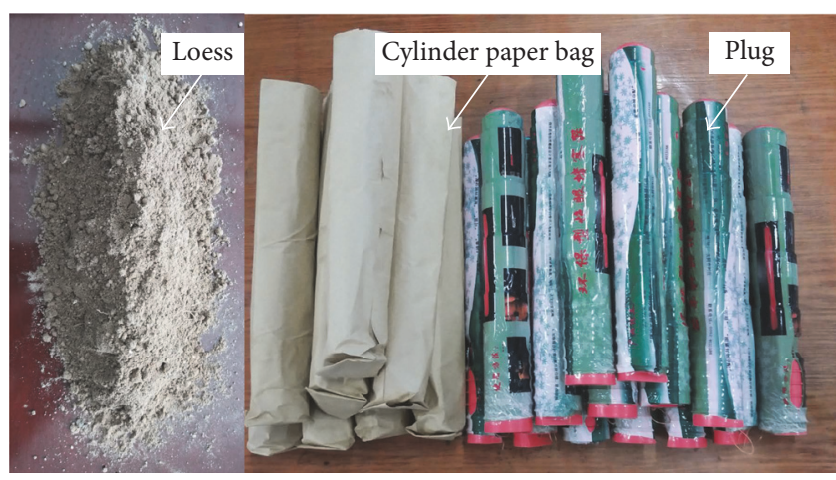

FIGURE 5: Test samples in the blocking impact test.

blockage effect of the clay stemming was directly related to the degree of ramming of clay. When the degree of contact between the clay and inner wall of the steel pipe was different, the bearing load was different. In order to fully achieve the blockage effect of the sample, sample group A should be puddled. The sliding wedge block of group B was hit as hard as possible, such that the sample was closely contacted with the inner wall of the steel pipe.

\section{Test Results and Analysis}

The research results show that the longer motion time and the lower exit velocity of the stemming from the hole could prolong the action time of the detonation gas, prevent the rapid attenuation of stress wave, fully utilize the blasting energy, and act as the gas wedge. The radial cracks are further extended to the depth of the rock mass movement or throw. In the test, the absolute movements of the head and tail of the stemming were measured using a tape, and the absolute difference between the calculations was considered as the compression deformation. The motion time of stemming in the blast hole was calculated using the high-speed camera. Based on the analysis of the test stress waves and high-speed photography images, the relationship between the impact incident energy and motion time and that between the impact incident energy and compression deformation of the samples in the hole were obtained. Further, the deformation and failure characteristics of the test were analyzed. The purpose was to analyze the blockage effect of clay stemming and plug. The physical and mechanical parameters of the sample under impact load are listed in Table 3. It can be observed that, for the clay stemming and plug, the impact incident energy is 119.91-568.22 J and 114.35-360.25 J, respectively; the motion time in the hole is $2.82-16.08 \mathrm{~ms}$ and $1.80-9.74 \mathrm{~ms}$, respectively; the compression deformation is $2-9.7 \mathrm{~cm}$ and $2.3-10.1 \mathrm{~cm}$, respectively.

4.1. Motion Time in the Hole of the Sample. Figure 6 shows the relationship between the impact incident energy and motion time in the hole for different blockage samples. The impact incident energy is approximately linear with the motion time in the hole. Under the condition of the same impact incident energy, the motion time of the plug in the hole is longer than that of the clay stemming. According to the fitting curve, when the impact incident energy is in the range of 100-500 J, compared with the clay stemming, the motion time of the plug in the hole can be extended by $14 \%-63 \%$ by using the plug. It can be observed that the blockage effect of the plug is better, which can fully utilize the explosive performance.

4.2. Compression Deformation of the Sample. Figure 7 shows the relationship between the impact incident energy and end movement for different blockage samples. Figure 8 shows the relationship between the impact incident energy and compression deformation. There is a positive correlation 
TABLE 3: Physical and mechanical parameters of different samples under impact load.

\begin{tabular}{lccccccccc}
\hline Sample & $L(\mathrm{~cm})$ & $\rho\left(\mathrm{kg} / \mathrm{m}^{3}\right)$ & $P(\mathrm{MPa})$ & $E_{I}(\mathrm{~J})$ & $t(\mathrm{~ms})$ & EL $(\mathrm{cm})$ & TL $(\mathrm{cm})$ & WL $(\mathrm{cm})$ & Remarks \\
\hline A1 & 28.0 & 918 & 0.5 & 119.91 & 2.82 & 2.4 & 0.4 & 2.0 \\
A2 & 28.4 & 918 & 0.6 & 177.48 & 7.00 & 2.5 & 0.3 & 2.2 \\
A3 & 27.8 & 918 & 0.7 & 202.01 & 8.44 & 3.5 & 0.3 & 3.2 \\
A4 & 27.9 & 918 & 0.8 & 248.23 & 8.78 & 5.3 & 0.5 & 4.8 \\
A5 & 27.9 & 918 & 0.9 & 282.90 & 9.66 & 6.7 & 0.6 & 6.1 \\
A6 & 27.9 & 918 & 0.9 & 275.45 & 7.98 & 8.5 & 1.0 & 7.5 \\
A7 & 28.2 & 918 & 1.0 & 307.97 & 9.98 & 8.2 & 0.4 & 7.8 \\
A8 & 28.2 & 918 & 1.1 & 353.90 & 11.08 & 10.9 & 1.2 & 9.7 \\
A9 & 27.8 & 918 & 1.2 & 411.51 & 16.08 & 14.6 & - & - \\
A10 & 27.7 & 918 & 1.2 & 402.56 & 13.54 & 11.5 & 5.2 & 6.3 \\
A11 & 27.8 & 918 & 1.3 & 510.66 & 15.00 & 15.4 & - & - \\
A12 & 28.1 & 918 & 1.3 & 568.22 & 14.40 & 17.9 & - & Run out \\
B1 & 27.5 & 1890 & 0.5 & 114.35 & 1.80 & 2.8 & 0.5 & Run out \\
B2 & 28.0 & 1839 & 0.6 & 182.87 & 5.38 & 5.9 & 0.4 & 2.3 \\
B3 & 27.1 & 1808 & 0.7 & 190.58 & 6.10 & 7.2 & 0.5 & Run out \\
B4 & 26.9 & 1867 & 0.8 & 228.12 & 6.90 & 8.5 & 0.9 & 6.7 \\
B5 & 27.8 & 1958 & 0.9 & 292.59 & 7.04 & 10.2 & 1.1 & 7.6 \\
B6 & 28.2 & 1914 & 1.0 & 305.32 & 7.38 & 11.5 & 1.4 & 9.1 \\
B7 & 28.4 & 1881 & 1.1 & 342.45 & 9.74 & 12.8 & - & -10.1 \\
B8 & 28.1 & 1983 & 1.1 & 360.25 & 8.78 & 13.8 & - & -
\end{tabular}

$P$, nitrogen pressure; $E_{I}$, impact incident energy; $t$, motion time of sample in the hole; EL, end movement of the sample; TL, tail movement of the sample; and $\mathrm{WL}$, compression deformation of the sample.

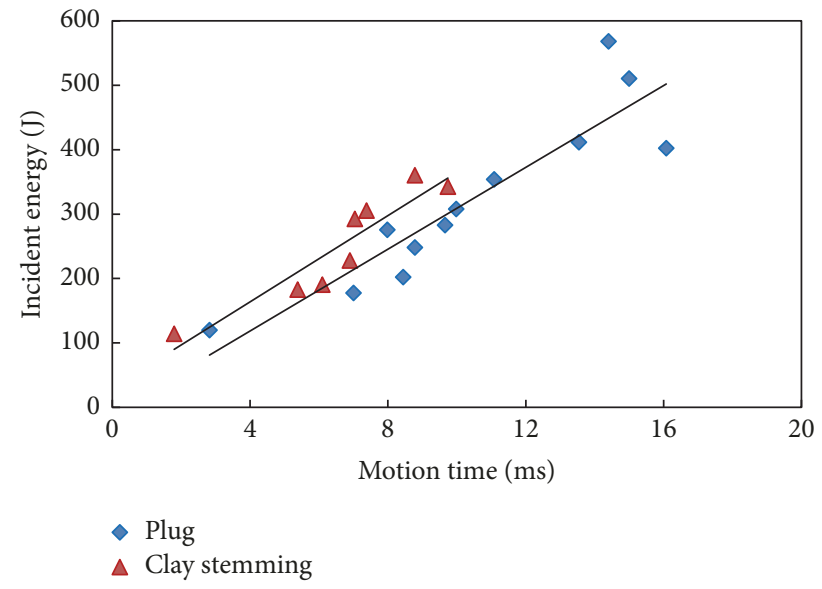

FIGURE 6: Relationship between the impact incident energy and motion time.

between the impact incident energy and end movement and between the impact incident energy and compression deformation.

By comparing and analyzing Figures 7 and 8 , the regression line between the end movement of the plug and clay stemming is close, and hence, the difference between the movement and compression is not evident. The results show that the plug and the clay stemming have good blockage effect. Under the condition of the same impact incident energy, the end movement and compression deformation of the plug in the hole are larger than those of the clay stemming.

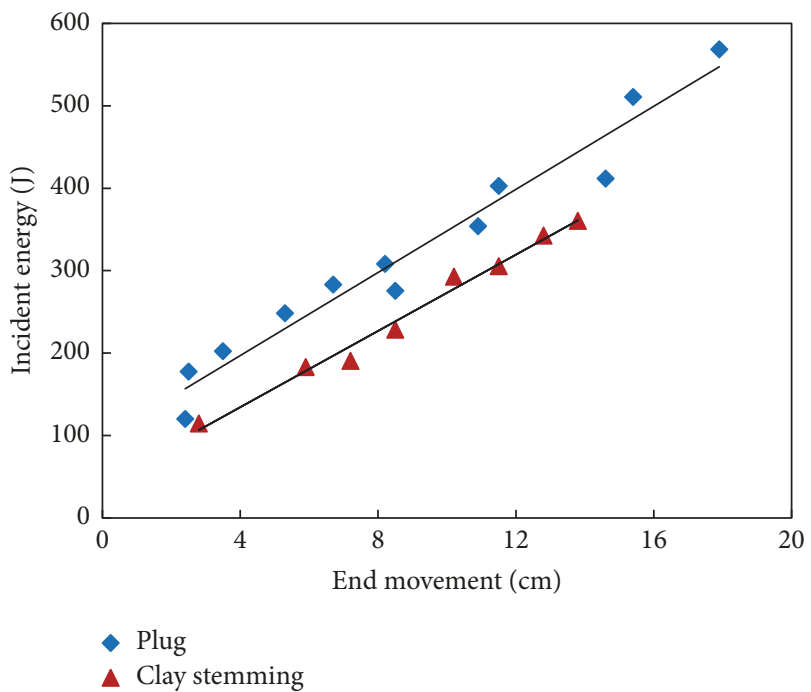

FIGURE 7: Relationship between the impact incident energy and end movement.

According to the fitting curve, when the impact incident energy is in the range of $100-500 \mathrm{~J}$, compared with the clay stemming, the end movement and compression deformation of the plug in the hole can be reduced by $19 \%-54 \%$ and $22 \%-66 \%$, respectively, by using the plug; furthermore, the hole wall friction resistance is greater and the blockage effect is better. However, when the impact incident energy is small, the movements of samples A1 and B1 are relatively close. The compression deformation of sample A10 is unique, 
TABLE 4: Main parameters of the industrial test tunnels.

\begin{tabular}{|c|c|c|c|c|c|c|c|}
\hline Name & Properties & Section shape & Lithology & $\begin{array}{l}\text { Dimensions } \\
\left(W \times H, \mathrm{~m}^{2}\right)\end{array}$ & $\begin{array}{c}\text { WI } \\
\left(\mathrm{N} / \mathrm{M}, \mathrm{m}^{3} / \mathrm{h}\right)\end{array}$ & $\begin{array}{c}\text { GQ } \\
\left(\mathrm{m}^{3} / \mathrm{min}\right)\end{array}$ & Drilling way \\
\hline $\begin{array}{l}2415 \\
\text { roadway }\end{array}$ & $\begin{array}{l}\text { Coal rock, } \\
f=2-4\end{array}$ & Rectangle & $\begin{array}{c}\text { Coal arenaceous } \\
\text { shale interbed }\end{array}$ & $4.20 \times 2.45$ & $0.6 / 0.7$ & 0.3 & YT2 air-jack leg drill \\
\hline $\begin{array}{l}\text { Return } \\
\text { entry }\end{array}$ & $\begin{array}{l}\text { Rock, } \\
f=5-6\end{array}$ & $\begin{array}{l}\text { Semicircular } \\
\text { arch }\end{array}$ & $\begin{array}{l}\text { Siltstone sandy } \\
\text { mudstone } \\
\text { interbed }\end{array}$ & $5.75 \times 1.50$ & $5 / 25$ & 0.5 & $\begin{array}{l}\text { CMJ2-27 hydraulic } \\
\text { jumbo }\end{array}$ \\
\hline
\end{tabular}

WI, N/M, water inflow; normal/maximum water inflow; and GQ, absolute gas emission quantity.

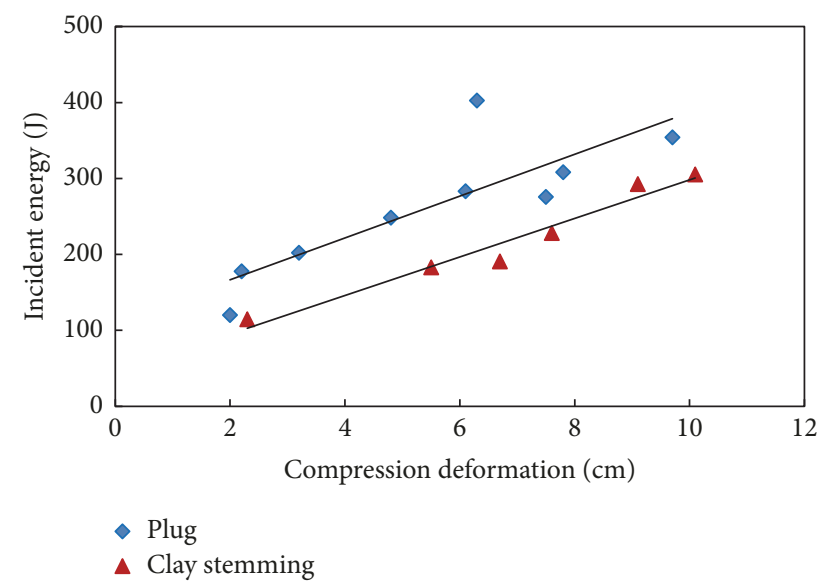

FIGURE 8: Relationship between the impact incident energy and compression deformation.

which is related to the quality of the artificial loading sample.

4.3. Deformation Characteristics of the Sample. The deformation process of the sample under the impact load can be clearly recorded using the high-speed camera. Figure 9 is the impact failure process of the sample in the simulated hole. First, the plug instantly burst into the first bursting cylinder under the impact load, which resulted in rapid movement and expansion of the bursting cylinder. At that time, the wedge plug had not yet moved owing to the initial pretightening force during loading. Subsequently, the three bursting cylinders moved and expanded gradually, which resulted in close contact with the hole wall and produced friction resistance. Finally, the wedge plug moved.

When the impact incident energy was small, the wedge plug at the end of the plug only produced a slight movement, as shown in Figure 9(a). When the impact incident energy was sufficiently large, the end of the plug rapidly generated compression deformation. The plug overall instantly moved fast toward the blast hole. When the plug moved toward the orifice, a collision took place between the sample and the left momentum bar. Under the action of the momentum rod, the sample was further compressed and deformed, resulting in a slight springback of the blast hole. At this time, the plug exited the blast hole, and the final state is shown in Figure 9(b). The deformation process of the clay stemming under the impact load was similar to that of the plug. First, the end of the clay stemming generated compression deformation, and subsequently, the plug overall moved toward the blast hole, which led to the overall inhomogeneous slip deformation. When the impact incident energy was small, the compression deformation of the clay stemming was small, as shown in Figure 9(c). When the impact incident energy was sufficiently large, the clay stemming also exited the blast hole, as shown in Figure $9(\mathrm{~d})$. In the test, the loess flew out of the observation tank with the clay stemming, which resulted in the decomposition of the force along the ring; further, the radial force was reduced, and the compression deformation of the clay stemming was smaller than the actual value.

After the impact load, the samples were removed as shown in Figure 10. In addition to the A1 sample, the other impact plugs were in the first bursting cylinder; further, the first expansion cylinders with a large number of radial scratches exhibited apparent damage, and the second and third bursting cylinders exhibited less damage. The samples A9, A11, and A12 that exited the blast hole produced large cracks at the opening of the fixed wedge block, whereas the other samples did not. The cracks were caused by the instant impact of the strong incident energy.

The test results show that samples A9, A11, A12, B7, and B8 exited the blast hole. From Table 3, it can be concluded that, when the impact incident energy is greater than $410 \mathrm{~J}$, the plug will exit the hole, and when the impact incident energy is greater than $340 \mathrm{~J}$, the clay stemming will exit the hole. Therefore, more energy is required for the plug to exit the hole. It can be observed that the blockage effect of the plug is better, which can fully utilize the explosive performance and improve the blasting effect of rock mass. The test results demonstrate that the structure design of the plug is reasonable and advantageous. Under the same working conditions, the stemming length can be shortened by the plug.

\section{Underground Industrial Test}

The industrial test was carried out in 2415 roadway, 404 area, $8^{\#}$ layer of the Yungang Coal Mine of the Datong Coal Mine Group and the return entry of Wuyang Coal Mine in Lu'an Group. The main parameters of the tunnels are listed in Table 4, and the drilling pattern and charge weight are listed in Tables 5 and 6. A hexagon hollow steel rod with the diameter of $25 \mathrm{~mm}$ and length of $3000 \mathrm{~mm}$ and a linestyled drill with the diameter of $42 \mathrm{~mm}$ were used for the wet drilling on the 2415 roadway and the return entry. The 

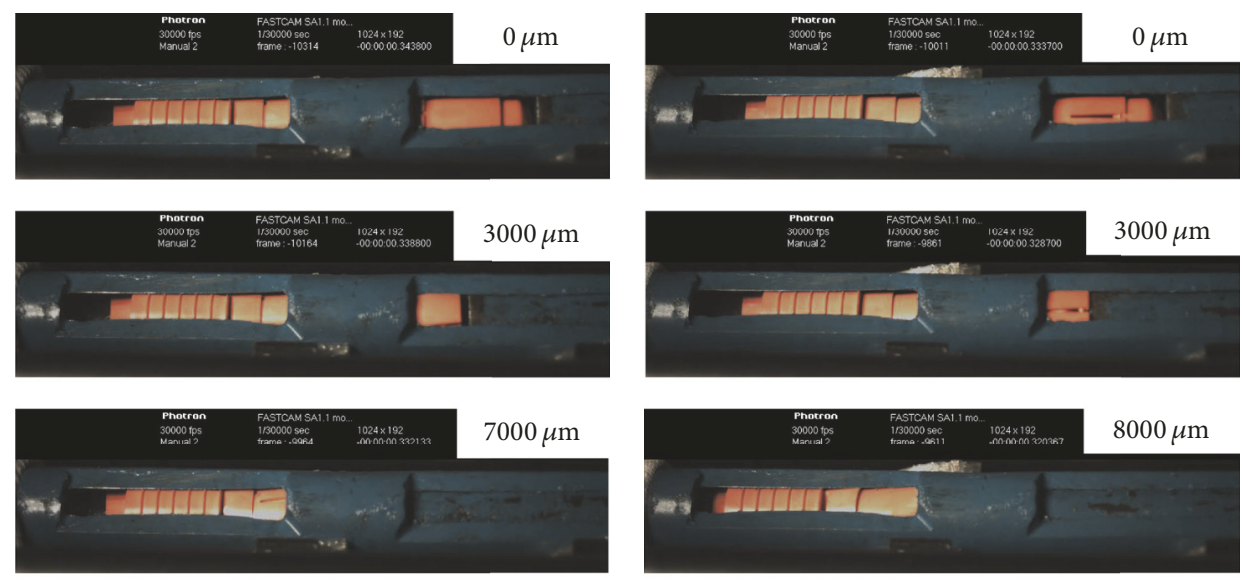

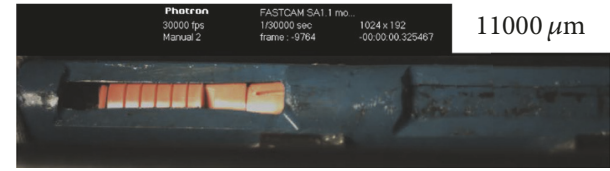

(a) A8, $353.90 \mathrm{~J}$
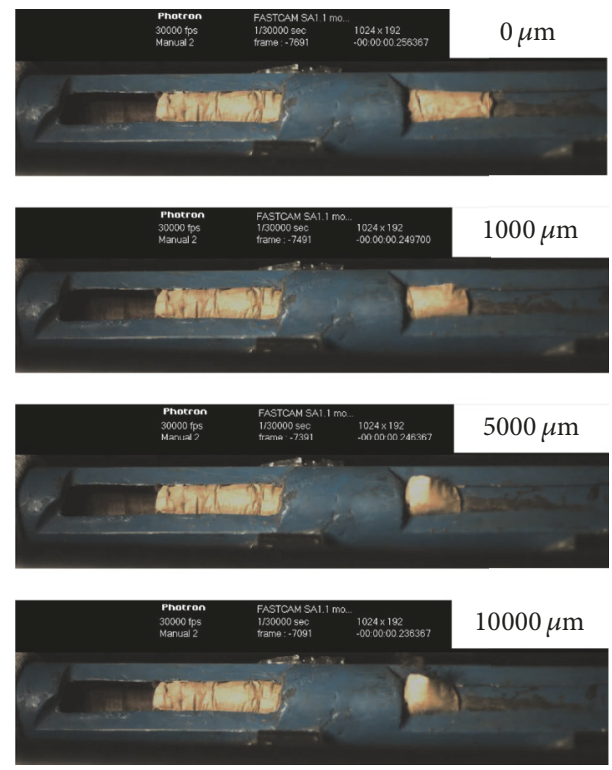

(c) B3, 190.58 J

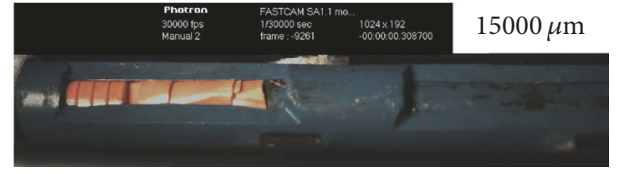

(b) A11, 510.66 J
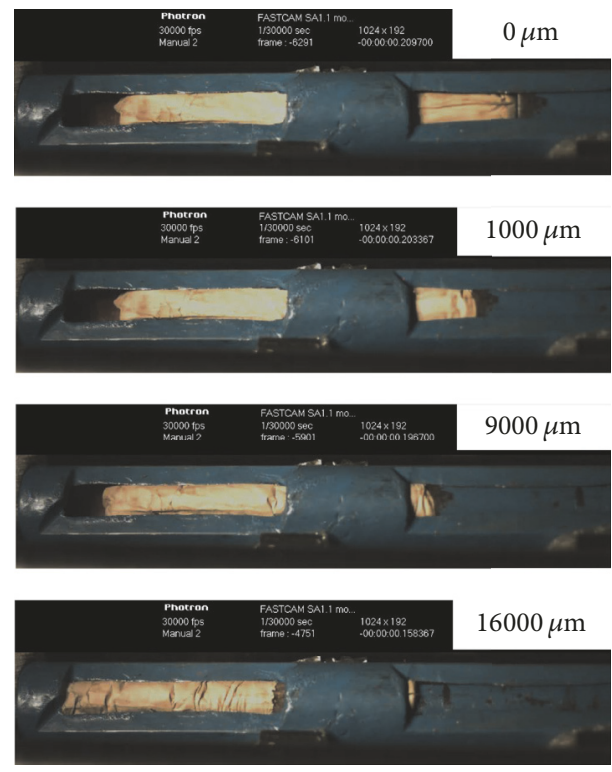

(d) $\mathrm{B} 8,360.25 \mathrm{~J}$

FIGURE 9: Impact failure process of typical samples at different test times.

TABLE 5: Drilling pattern and charge weight in 2415 roadway.

\begin{tabular}{|c|c|c|c|c|c|c|c|c|}
\hline \multirow{2}{*}{ Hole name } & \multirow{2}{*}{ Number } & \multirow{2}{*}{ Hole depth (m) } & \multicolumn{2}{|c|}{ Angle $\left(^{\circ}\right)$} & \multirow{2}{*}{ Total charge (kg) } & \multirow{2}{*}{ Firing sequence } & \multirow{2}{*}{ Connection way } & \multirow{2}{*}{ Filling way } \\
\hline & & & Horizontal & Vertical & & & & \\
\hline Cut hole & $1-6$ & 2.0 & 73 & 90 & $1.0 \times 6$ & 1 & & \\
\hline Auxiliary hole holes & $7-10$ & 1.8 & 90 & 90 & $0.8 \times 4$ & 2 & & \\
\hline Trim hole & $11-24$ & 1.8 & 83 & 83 & $0.6 \times 14$ & 3 & Series & Fully filled \\
\hline Bottom hole & $25-31$ & 1.8 & 83 & 83 & $0.6 \times 7$ & 4 & & \\
\hline Total & 31 & & & & 21.8 & & & \\
\hline
\end{tabular}


TABLE 6: Drilling pattern and charge weight in return entry.

\begin{tabular}{|c|c|c|c|c|c|c|c|c|}
\hline \multirow{2}{*}{ Hole name } & \multirow{2}{*}{ Number } & \multirow{2}{*}{ Hole depth (m) } & \multicolumn{2}{|c|}{ Angle ${ }^{\circ}$} & \multirow{2}{*}{ Total charge $(\mathrm{kg})$} & \multirow{2}{*}{ Firing sequence } & \multirow{2}{*}{ Connection way } & \multirow{2}{*}{ Filling way } \\
\hline & & & Horizontal & Vertical & & & & \\
\hline Intermediate hole & $1 \sim 4$ & 2.7 & $90^{\circ}$ & \multirow{5}{*}{$85^{\circ}$} & $1.6 \times 4$ & 1 & \multirow{8}{*}{ Series } & \multirow{8}{*}{ Full filled } \\
\hline Intermediate hole & 5 & 2.7 & $90^{\circ}$ & & $0.6 \times 1$ & 2 & & \\
\hline Cut hole & $6 \sim 11$ & 2.5 & $83^{\circ}$ & & $1.6 \times 6$ & 2 & & \\
\hline Auxiliary hole & $12 \sim 25$ & 2.5 & $90^{\circ}$ & & $1.6 \times 14$ & 3 & & \\
\hline Brukup borehole & $26 \sim 45$ & 2.5 & $90^{\circ}$ & & $1.4 \times 20$ & 4 & & \\
\hline Trim hole & $46 \sim 70$ & 2.5 & $87^{\circ}$ & & $0.6 \times 25$ & 5 & & \\
\hline Bottom hole & $71 \sim 82$ & 2.5 & $90^{\circ}$ & $85^{\circ}$ & $1.2 \times 12$ & 5 & & \\
\hline Total & 82 & & & & 96.4 & & & \\
\hline
\end{tabular}

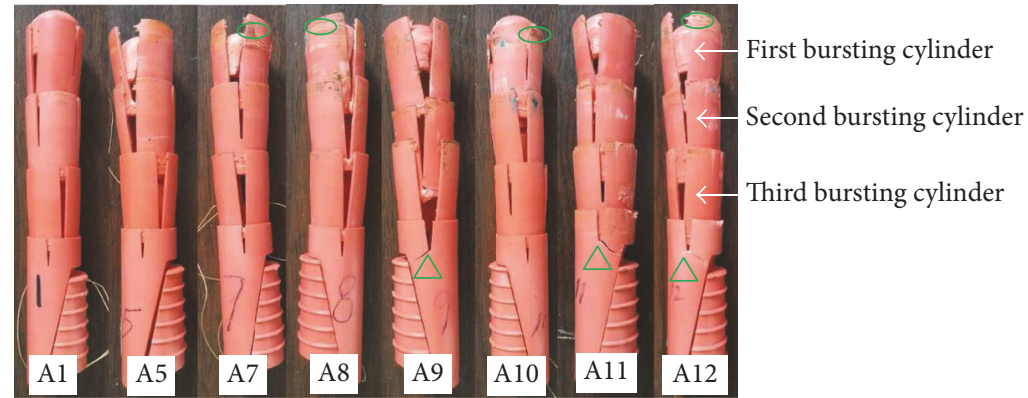

$\bigcirc$ Scratch
$\triangle$ Crack

FIGURE 10: The scratch and crack of the plug after the impact test.

forward charge adopted a third-grade coal mine permissible emulsion explosive. The diameter, length, and weight of cartridge were $32 \mathrm{~mm}, 200 \mathrm{~mm}$, and $200 \mathrm{~g}$, respectively. The tunnel hole depths were $1.8 \mathrm{~m}$ and $2.5 \mathrm{~m}$, and the stemming lengths were $600 \mathrm{~mm}$ and $800 \mathrm{~mm}$ for the clay stemming. Two sets of $280 \mathrm{~mm}$ length environmentally friendly blast hole plugs were used, and the blast hole charge weight was optimized. The blockage blasting tests with 31 and 82 cycles were carried out. In most cases, a large amount of clay is carried by the worker in a coal mine. The weight of the clay stemming of $280 \mathrm{~mm}$ length is $600 \mathrm{~g}$, and that of the plug is $140 \mathrm{~g}$; the weight is reduced by $77 \%$, which significantly reduces the labor intensity. The blockage time of 60 and 20 vertical upward boreholes was counted for the clay stemming and plug, the blockage time of the horizontal boreholes was $51 \mathrm{~s}$ and $20 \mathrm{~s}$, respectively, and that of the vertical upward boreholes was $98 \mathrm{~s}$ and $35 \mathrm{~s}$, respectively; the blockage time was decreased by $61 \%$ and $64 \%$, respectively, and the blockage efficiency was significantly improved by the plug. The specific blasting results are presented in Table 7 and Figure 11.

The results of the industrial test show that, compared with the clay stemming, using the plug can reduce the unit explosive consumption by $28.4 \%$ and $19.7 \%$ (average of $24 \%$ ), respectively, improve the footage driving cycle by $8.7 \%$ and $9.1 \%$ (average of $8.9 \%$ ), respectively, increase the blasting efficiency by $8.6 \%$ and $1.0 \%$ (average of $4.8 \%$ ), respectively, reduce the dust concentration by $32.1 \%$ and $15.1 \%$ (average of $23.6 \%$ ), respectively, lower the harmful gas content by $13.2 \%$ and $8.8 \%$ (average of $11.0 \%$ ), respectively, and increase the blockage cost per unit length by $3.9 \%$ and $31.2 \%$ (average of $17.5 \%$ ), respectively, in the 2415 roadway and the return entry. It can apparently decrease the labor intensity, reduce the blockage time, reduce the boulder yield, increase the halfhole marks, render the blasting rock block more uniform, and significantly improve the blockage speed and loading efficiency. Therefore, the use of the environmentally friendly blast hole plug could improve the effect of rock blasting, prevent premature detonation gas emissions, and prolong the action time of the detonation gas, with low cost of rock breaking.

\section{Conclusions}

(1) The test results show that when the plug was used under the condition of the same impact incident energy, the motion time in the hole was prolonged by $14 \%-63 \%$ and the end movement and compression deformation decreased by $19 \%-54 \%$ and $22 \%-66 \%$, respectively, as compared with clay stemming. When the impact incident energy was greater than $410 \mathrm{~J}$, the plug exited the hole; when the impact incident energy was greater than $340 \mathrm{~J}$, the clay stemming exited the hole. Therefore, more energy is required for the plug to exit the hole. It could be observed that the blockage effect of the plug was better, which can fully utilize the explosive performance and improve the blasting effect of rock mass. This demonstrates that the structure design of the plug is reasonable and advantageous. 
TABLE 7: Main test parameters between traditional clay stemming and new plug.

\begin{tabular}{|c|c|c|c|c|c|c|}
\hline \multirow{2}{*}{ Items } & \multicolumn{3}{|c|}{2415 roadway } & \multicolumn{3}{|c|}{ Return entry } \\
\hline & Clay stemming & Plug & Ratio & Clay stemming & Plug & Ratio \\
\hline Hole depth (m) & 1.8 & 1.8 & - & 2.5 & 2.5 & - \\
\hline Cycle number (number) & 31 & 31 & - & 82 & 82 & - \\
\hline Cycle charge (kg) & 21.8 & 17.0 & $128 \%$ & 96.4 & 84.6 & $114 \%$ \\
\hline Footage driving cycle (m) & 1.50 & 1.63 & $92 \%$ & 2.2 & 2.4 & $92 \%$ \\
\hline Unit explosive consumption $\left(\mathrm{kg} / \mathrm{m}^{3}\right)$ & 1.41 & 1.01 & $140 \%$ & 1.98 & 1.59 & $125 \%$ \\
\hline Blast hole utilization factor (\%) & 83.3 & 90.5 & $92 \%$ & 88.0 & 88.9 & $99 \%$ \\
\hline Cyclic block number (piece) & 8.4 & 2.8 & $300 \%$ & 9.2 & 3.3 & $279 \%$ \\
\hline Half-hole marks (strip) & 2.5 & 8.3 & $30 \%$ & 3.8 & 8.9 & $43 \%$ \\
\hline Cyclic over excavation $(\mathrm{cm})$ & 5.1 & 4.2 & $121 \%$ & 6.3 & 4.8 & $131 \%$ \\
\hline Dust concentration $\left(\mathrm{mg} / \mathrm{m}^{3}\right)$ & 336 & 228 & $147 \%$ & 456 & 387 & $118 \%$ \\
\hline Harmful gas content $(\mathrm{L} / \mathrm{kg})$ & 38 & 33 & $115 \%$ & 34 & 31 & $110 \%$ \\
\hline Blockage cost $(\mathrm{RMB} / \mathrm{m})$ & 16.00 & 16.63 & $96 \%$ & 28.64 & 37.58 & $76 \%$ \\
\hline
\end{tabular}

Ratio, the ratio of clay stemming to plug.

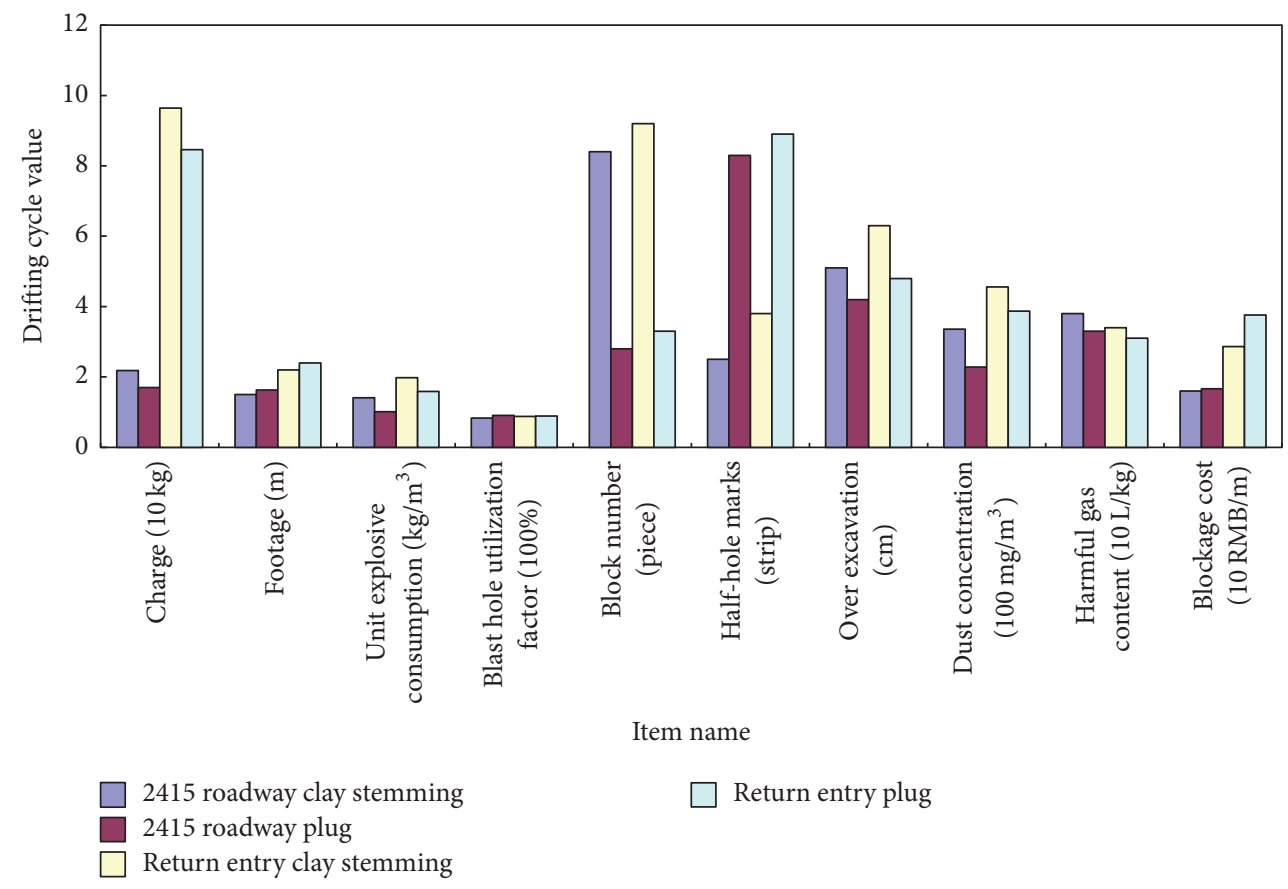

FIgURE 11: Comparison of blasting effect between traditional clay stemming and new plug.

(2) The results of the industrial test show that, compared with the clay stemming, using the plug can reduce the unit explosive consumption by $24 \%$, improve the footage driving cycle by $8.9 \%$, increase the blasting efficiency by $4.8 \%$, reduce the dust concentration by $23.6 \%$, lower the harmful gas content by $11.0 \%$, and increase the blockage cost per unit length by $17.5 \%$ in the 2415 roadway and return entry on average. It can apparently decrease the labor intensity, reduce the blockage time, reduce the boulder yield, increase the half-hole marks, render the blasting rock block more uniform, and significantly improve the blockage speed and loading efficiency.
(3) An environmentally friendly blast hole plug was designed with a composite structure system, including an impact plug, multistage bursting cylinder with compressible burst, water stemming inner core with high-efficiency dust reduction and environmental protection, and wedge plug. The hole plug could be used as a source power of plug burst using an explosive shock wave, achieve multilevel buffer compression burst, extend the action time of the explosion gas, improve the utilization ratio of explosive blasting, improve the embrasure blockage effect, and improve the blasting effect. It can also be effectively combined and reasonably configured according to the hole 
depth and stemming length, which provides a new method for blast hole blockage.

\section{Conflicts of Interest}

The authors declare that they have no conflicts of interest.

\section{Acknowledgments}

This research was financially supported by the State Key Research Development Program of China (Grant no. 2016YFC0801401) and Shanxi Provincial Science and Technology Development Plan (Industrial) (2014032100305). The authors specially thank Professor Xibing Li and Dr. Qiuhong $\mathrm{Wu}$ of Central South University for their help in the testing.

\section{References}

[1] L. Yuan, J.-H. Xue, Q.-S. Liu, and B. Liu, "Surrounding rock stability control theory and support technique in deep rock roadway for coal mine," Journal of Coal Science \& Engineering (China), vol. 36, no. 4, pp. 535-543, 2011.

[2] L. Yuan, Y. Qin, Y.-P. Cheng, J.-B. Meng, and J. Shen, "Scenario predication for medium-long term scale of coal mine methane drainage in China," Meitan Xuebao/Journal of the China Coal Society, vol. 38, no. 4, pp. 529-534, 2013.

[3] C. Zhang, S. Tu, M. Chen, and L. Zhang, "Pressure-relief and methane production performance of pressure relief gas extraction technology in the longwall mining," Journal of Geophysics and Engineering, vol. 14, no. 1, pp. 77-89, 2017.

[4] C. Zhang, S. Tu, Q. Bai, G. Yang, and L. Zhang, "Evaluating pressure-relief mining performances based on surface gas venthole extraction data in longwall coal mines," Journal of Natural Gas Science and Engineering, vol. 24, pp. 431-440, 2015.

[5] L.-J. Dong, J. Wesseloo, Y. Potvin, and X.-B. Li, "Discriminant models of blasts and seismic events in mine seismology," International Journal of Rock Mechanics \& Mining Sciences, vol. 86, pp. 282-291, 2016.

[6] L. Dong, J. Wesseloo, Y. Potvin, and X. Li, "Discrimination of mine seismic events and blasts using the fisher classifier, naive bayesian classifier and logistic regression," Rock Mechanics and Rock Engineering, vol. 49, no. 1, pp. 183-211, 2016.

[7] L. Dong, W. Shu, X. Li, G. Han, and W. Zou, "Three Dimensional Comprehensive Analytical Solutions for Locating Sources of Sensor Networks in Unknown Velocity Mining System," IEEE Access, vol. 5, pp. 11337-11351, 2017.

[8] C. J. Konya, "Problems with deck-loaded blastholes," Engineering \& Mining Journal, vol. 197, no. 7, pp. 73-73, 1996.

[9] K. H. Kutter and C. Fairhurst, "On the fracture process in blasting," International Journal of Rock Mechanics \& Mining Science \& Geomechanics Abstracts, vol. 8, no. 3, pp. 181-202, 1971.

[10] W. I. Duvall, "Strain-wave shapes in rock near explosions," Geophysics, vol. 18, no. 2, pp. 310-323, 1953.

[11] B. A. Cummins and I. A. Given, "Mining Engineering Handbook," in American Review of Respiratory Disease, vol. 2, pp. 203-206, 1973.

[12] N. T. Hagan and B. J. Kennedy, "Practical approach to the reduction of blasting nuisances from surface operations: aust min, V69, N11, Nov 1977, P36-46," International Journal of Rock
Mechanics \& Mining Sciences \& Geomechanics Abstracts, vol. 15, no. 3, 65 pages, 1978.

[13] C. J. Konya, "Comparison of different blast design methods," Engineering \& Mining Journal, vol. 197, no. 9, 1996.

[14] Z. G. Yang, "Study on hole blasting congestion," Blasting, vol. 4, pp. 6-11, 1985 (Chinese).

[15] Y. Luo and Z. Shen, "Investigation on length of stemming material and its effect in hole-charged blasting," in Mechanics in Engineering, vol. 28, pp. 48-52, 2006.

[16] S. K. Sharma and P. Rai, "Investigation of crushed aggregate as stemming material in bench blasting: a case study," Geotechnical and Geological Engineering, vol. 33, no. 6, pp. 1449-1463, 2015.

[17] H. Cevizci and H. T. Özkahraman, "Effect of Plaster Stemming to Blast Fragmentation at Clay Quarries," in 22ND World Minig Congress \& Expo, vol. 1, pp. 551-554, Istanbul, Turkey, MC-2011.

[18] L. F. Marinho, H. G. Vasconcelos, B. Lusk, and G. A. Rapucci, "Achieving effective confinement through utilization of nonNewtonian fluid mixture as stemming structure," REM - International Engineering Journal, vol. 70, no. 1, pp. 77-83, 2017.

[19] S. Wang C, "Application of special rigid blast-hole-plugging materials in the blasting demolition of RCC cofferdam in three gorges project," Blasting, vol. 24, no. 3, pp. 93-96, 2007.

[20] P. N. Worsey, Blast plug and stemming construction for blast holes. American patent: US5247886. 1993.

[21] R. D. Skaggs, Blast plug. American patent: US5841060. 1998.

[22] S. Jenkins and T. S. Jenkins, Article ID 6213212, Spherical stemming plug and method of use. American patent: US 6213212 B1. 2001.

[23] P. C. Shann, Stemming arrangement and method for blast holes. American patent: US6386111. 2002.

[24] M. Sazid, M. R. Saharan, and T. N. Singh, "Effective explosive energy utilization for engineering blasting - Initial results of an inventive stemming plug, SPARSH," in Proceedings of the 12th International Congress on Rock Mechanics of the International Society for Rock Mechanics, ISRM 2011, pp. 1265-1268, chn, October 2011.

[25] B. S. Choudhary and P. Rai, "Stemming plug and its effect on fragmentation and muckpile shape parameters," International Journal of Mining and Mineral Engineering, vol. 4, no. 4, pp. 296311, 2013.

[26] B. Unver and A. A. Ozozen, "Assessment of the use of plastic water stemming cartridges in underground blasting operations," Mining Technology Imm Transactions, vol. 107, pp. A1-A5, 1998.

[27] D. W. Kang, "Self-supporting air tube for blasting and method of blasting rock using the same," American patent: WO/2006/ 095938. 2006.

[28] L. Jin, M. Yu, J. Liu et al., "Experimental study on reducing the dust of explosion by the new water stemming," Journal of China Coal Society, vol. 32, no. 3, pp. 31-35, 2007.

[29] B. Wang, S. Liao, and C. Li, "Preparation and characterization of water swelling rubber by bentonite/acrylamide grafted and modified natural rubber," Journal of Materials Science \& Engineering, vol. 33, no. 3, pp. 415-419, 2015.

[30] M. Dobrilovi, Z. Ester, and B. Jankovi, "Measurement in blast hole stem and influence of stemming material on blasting quality," Rudarsko-Geološko-Naftni Zbornik, vol. 17, no. 1, pp. 4753, 2005.

[31] H. Cevizci, "A new stemming application for blasting: a case study," Revista Escola de Minas, vol. 66, no. 4, pp. 513-519, 2013. 
[32] H. Cevizci and H. T. Ozkahraman, "The effect of blast hole stemming length to rockpile fragmentation at limestone quarries," International Journal of Rock Mechanics and Mining Sciences, vol. 53, pp. 32-35, 2012.

[33] X. Yang and M. Wang, Mechanism of Rock Crack Growth under Detonation Gas Loading, Explosion \& Shock Waves, 2001.

[34] X. L. Yao, F. Z. Pang, and X. U. Wei-Jun, Dynamic Response Analysis on Spherical Stem Bulkhead with Ribs under Hydrostatic and Dynamic Loads, Ship Building of China, 2007.

[35] J. Dai, Dynamic Behaviors and Blasting Theory of Rock, Press of Metallurgy Industry, Beijing, China, 2002.

[36] G. Ravichandran and G. Subhash, "Critical appraisal of limiting strain rates for compression testing of ceramics in a split hopkinson pressure bar," Journal of the American Ceramic Society, vol. 77, no. 1, pp. 263-267, 1994.

[37] X. B. Li, Rock Dynamics Fundamentals and Applications, Science Press, Beijing, China, 2014.

[38] X. Li, Q. Wu, M. Tao, L. Weng, L. Dong, and Y. Zou, "Dynamic Brazilian Splitting Test of Ring-Shaped Specimens with Different Hole Diameters," Rock Mechanics and Rock Engineering, vol. 49, no. 10, pp. 4143-4151, 2016. 


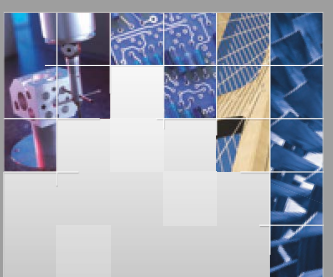

\section{Enfincering}
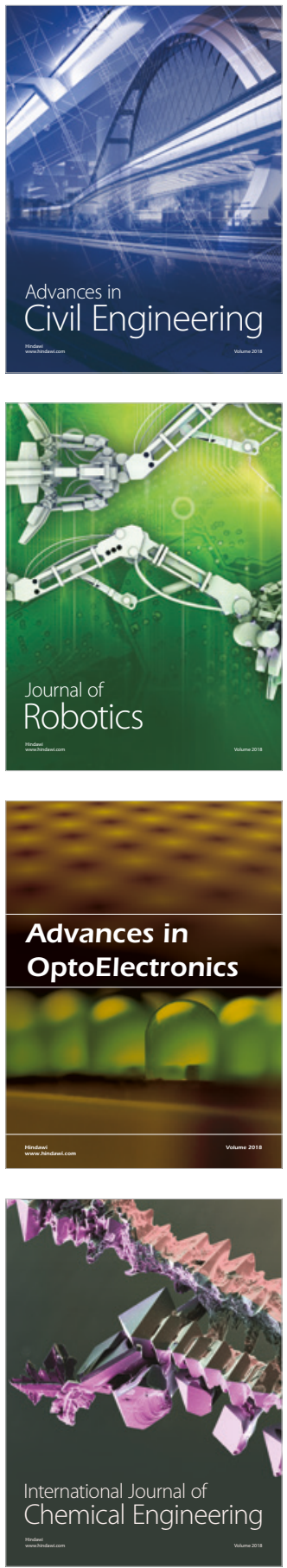

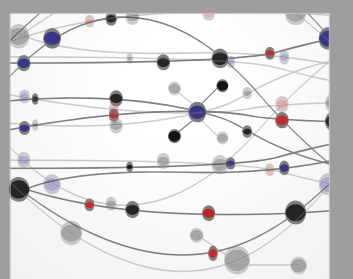

\section{Rotating \\ Machinery}

The Scientific World Journal

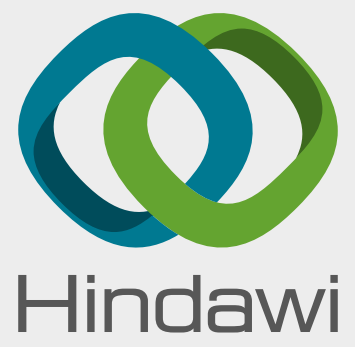

Submit your manuscripts at

www.hindawi.com
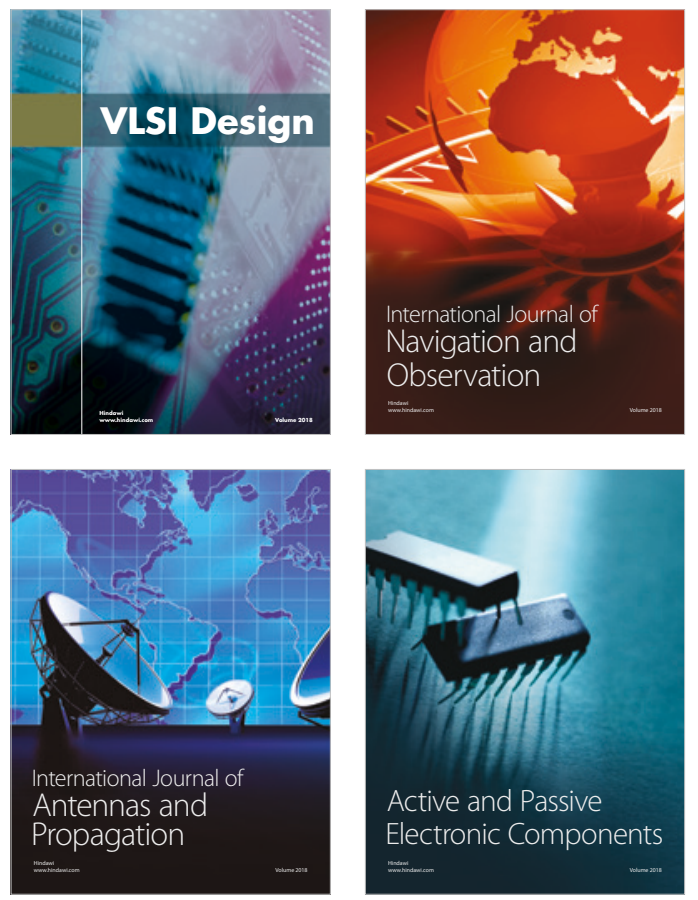
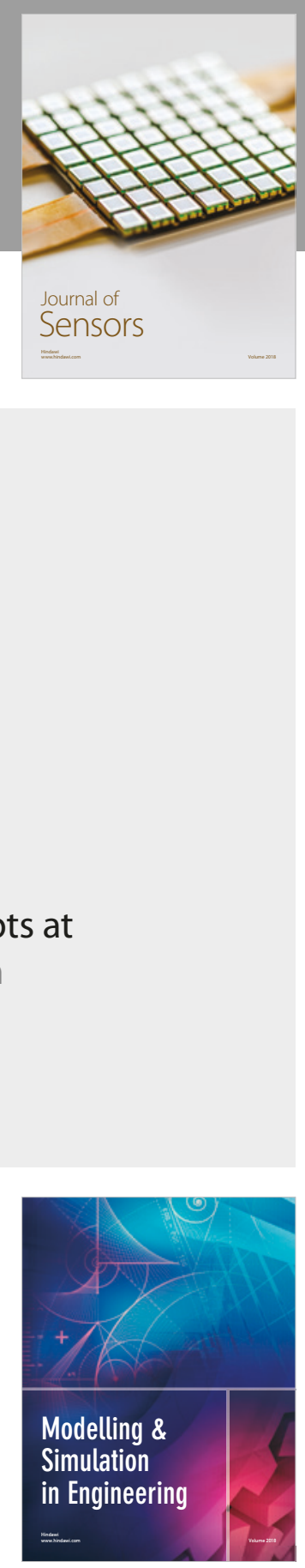

\section{Advances \\ Multimedia}
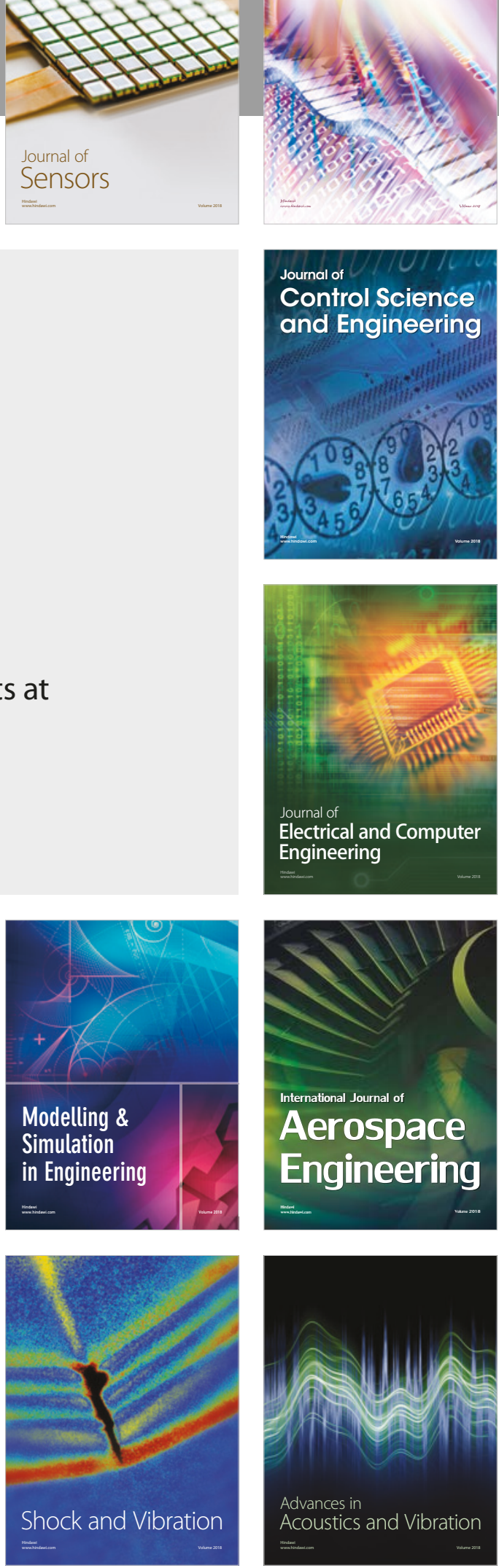